\title{
UŻYTECZNOŚĆ, EMPOWERMENT I PRACA SOCJALNA
}

\section{Streszczenie}

Użyteczność pracy socjalnej można uznać za wartość przydatną w realizacji założeń i celów stawianych przed systemem pomocy społecznej w społeczeństwie współczesnym. Z kolei idea empowermentu interpretowana w duchu samostanowienia jednostek i w duchu wrażliwości społecznej nie pozwala zapomnieć o tym, że brak uznania społecznego jest pozbawianiem podmiotowości i samostanowienia jednostek o sobie. W artykule zostały zaznaczone wzajemne powiązania pomiędzy użytecznością i empowermentem na obszarze pracy socjalnej, które mogą przyczyniać się do rozpoznawania kwestii społecznych w ich etycznym wymiarze oraz mogą pomagać w podejmowaniu i rozwiązywaniu problemów socjalnych odnoszących się zarówno do całości systemu pomocy społecznej, jak i do rozwiązywania problemów lokalnych z poszanowaniem wolności indywidualnej jednostek. Dzieje się tak wtedy, gdy użyteczność jest definiowana w duchu przydatności i praktycznego zastosowania powiązanych z działaniem na rzecz dobra dla innych, a idea empowermentu określa, że w pracy socjalnej nie można rezygnować z takiej wartości, jak upodmiotowienie jednostek i grup społecznych w kontekście ich samostanowienia o sobie i usamodzielniania.

Słowa kluczowe: użyteczność, empowerment, praca socjalna, samostanowienie, utylitaryzm, dobro dla innych.

\section{Wprowadzenie}

Użyteczność jako kryterium stanowiące podłoże dla podejmowania i rozwiązywania problemów społecznych zyskuje coraz większe uznanie w pracy socjalnej oraz 
praktyce zawodowej pracownika socjalnego*. W jakim więc wymiarze zasada użyteczności może być przydatna w pracy socjalnej i w jakim sensie może stanowić również kryterium aksjologicznej oceny pracy socjalnej? Jakie konsekwencje dla pracy socjalnej wynikają, jeśli użyteczność zostanie uznana za wartość podstawową? Przydatność zasady użyteczności wynika już z założeń, celów i funkcji pracy socjalnej oraz stojących wobec niej nowych zadań w społeczeństwie współczesnym. Z kolei użyteczność pracy socjalnej jest rozumiana w kategoriach utylitarnych, zwracających uwagę na skuteczność działania i systemową organizację całego systemu pomocy społecznej wraz z uzyskiwanymi efektami. Coraz częściej podkreśla się, że skuteczność działania systemu służb społecznych wiąże się z przewartościowaniem sposobu rozumienia zadań, celów i funkcji instytucji społecznych i co za tym idzie sposobów ich realizacji przez pracowników socjalnych. W tym sensie wzrasta utylitarna wartość pracy socjalnej mierzona kategorią użyteczności, natomiast, jak podkreślają Dorota A. Rybczyńska i Bożena Olszak-Krzyżanowska: „Wobec nowych (...) problemów społecznych zmienia się wizerunek współczesnego pracownika socjalnego. Wzrasta też (...) utylitarna wartość tej pracy. Utylitarna, to taka, która ma zastosowanie praktyczne, użytkowe" (Rybczyńska, Olszak-Krzyżanowska, 1995, s. 140). Zatem utylitarna wartość pracy socjalnej, podstawę której stanowi kryterium użyteczności, stanowi ważną etyczną miarę aksjologicznej oceny struktur systemu pomocy społecznej oraz zawodu pracownika socjalnego w społeczeństwie współczesnym opartym na zasadach demokracji i prawach człowieka, sprawiedliwości społecznej, autonomii, samostanowieniu o sobie, dystrybucji dóbr społecznych, dążeniu do dobrobytu oraz zysku i konsumpcji.

Jak więc rozumieć użyteczność pracy socjalnej oraz to, że jej wartość wynika także z zastosowania w praktycznych działaniach? W sensie ogólnym znaczy to tyle, że wartość pracy socjalnej jest mierzona i spostrzegana pozytywnie w odniesieniu do jej praktyczno-pragmatycznych i empirycznych wymiarów wynikających z podejmowanych działań, które mają przynosić korzyści dla jednostek i społeczeństwa oraz określać ich dobrostan. To sprawia, że należy na nowo zdefiniować, zmodyfikować i określić cele i wartości pracy socjalnej oraz pracownika socjalnego w duchu praktycznego działania, umiejętności umożliwiających wykonywanie nowych zadań wynikających z praktyki zawodowej, której podstawę stanowi właśnie użyteczność, co podkreśla D.A. Rybczyńska oraz B. Olszak-Krzyżanowska: „W proponowanym ujęciu utylitaryzm będzie dla nas raczej synonimem praktycyzmu i użyteczności pracy socjalnej, wyrażających się w podstawowych zadaniach tej działalności, takich jak: przygotowanie klientów do życia, rozumiane jako wdrażanie do

\footnotetext{
* W tekście tym nawiązuję do tez zawartych w moim artykule zatytułowanym Użyteczno-emancypacyjny potencjat dialoguldziatania dla dobra innych, które tutaj rozwijam: Maj (2017).
} 
samodzielności, odpowiedzialnej aktywności, przejawianie troski o dobro drugiego człowieka, troski wyrażającej się w dbałości o zaspokajanie potrzeb wszystkich osób bez względu na ich cechy społeczno-demograficzne, psychofizyczne czy też cechy podłoża społecznego, pomoc w rozwiązywaniu problemów pojawiających się w wyniku trudnych sytuacji życiowych, reagowanie na pojawiające się problemy i kwestie społeczne, planowanie zmian społecznych, animowanie działań społecznych, podejmowanie działań prowadzących do przeobrażeń środowiska, zwłaszcza w obrębie społeczności lokalnych" (ibidem, s. 141-142).

Użyteczność i praktyczne działania w pracy socjalnej odnoszą się więc do jasno zdefiniowanych wartości, takich jak samodzielność, aktywność, a przede wszystkim troska o innych, odpowiedzialność, które łączą się z taką wartością, jak traktowanie wszystkich z należnym szacunkiem i uznaniem niezależnie od przekonań i pochodzenia. To, co umożliwia praktyczne działania oraz wymierne efekty wynikające z działań służb społecznych i pracowników socjalnych, to właściwa ocena (rozpoznawanie) zjawisk i kwestii społecznych, w czym pomaga podejmowanie działań na rzecz aktywizacji społecznej, jako działań strategicznych ułatwiających rozpoznawanie oraz rozwiązywanie problemów odnoszących się do konkretnych grup i jednostek. Jeśli więc przyjmiemy, że użyteczność i praktyczność odnoszą się do takich wartości, jak samodzielność, troska o innych czy do działania na rzecz rozwiązywania problemów społecznych, to można wyciagnąć wniosek, że użyteczność jest pewnym uniwersalnym aspektem wynikającym z ogólnych założeń pracy socjalnej nakierowanych na proces uspołecznienia, który jest zarazem procesem upodmiotowienia, co uzasadnia w swoich poglądach społecznych twórca utylitaryzmu John Stuart Mill.

Utylitaryzm w ujęciu Milla sytuuje człowieka w określonym porządku społeczno-socjalnym, który jest jednym z najważniejszych elementów dla samostanowienia o sobie samym i w tym sensie praca socjalna, jako proces upodmiotowienia i socjalizacji, ma służyć człowiekowi. Dlatego, jak podkreśla D.A. Rybczyńska i B. Olszak-Krzyżanowska: „Praca socjalna jest bezinteresowna w tym sensie, że działania socjalne z definicji mają służyć człowiekowi i w związku z człowiekiem przebiegają, zgodnie z podstawową zasadą aksjologiczną, w myśl której człowiek i jego dobro są wartością podstawową, niepodważalną" (ibidem, s. 142). Dla Milla działania służące człowiekowi to działania chroniące jego autonomię, wolność indywidualną oraz prawo do samostanowienia. Natomiast wszelkie działania socjalne mają prowadzić do korzystnej zmiany sytuacji określonej jednostki, co wynika z działań na rzecz ogólnego polepszenia losu ludzkości. Tak więc w sposób oczywisty działania socjalne nie mogą naruszać autonomii jednostki i jej prawa do samostanowienia o sobie. Ale tym, co ma stanowić o działaniach socjalnych chroniących autonomię jednostki i zarazem mających przyczyniać się do polepszenia losu ludzkości, jest doprowadzenie jednostki do samodzielnego decydowania o własnym życiu. Cała struktura 
społeczna, w tym praca socjalna, ma przyczyniać się do rozwoju jednostki, w czym pomaga jej aktywność społeczna, co podkreśla Monika Małek: „W filozofii Milla obok autonomii i indywidualizmu ważne miejsce zajmuje aktywizm jednostki. Aby w pełni wykorzystać autonomię i własną indywidualność, należy przyjąć postawę aktywną społecznie, toteż zarówno działanie w kierunku samodoskonalenia siebie (poprzez edukację, kształtowanie charakteru itd.), jak działanie dla dobra innych ludzi czy też całego społeczeństwa (inicjowanie reform politycznych, działania charytatywne, edukacyjne itp.), są przez Milla uważane za pożądane - są nawet obywatelskim obowiązkiem. Myśliciel ten bardzo cenił ludzi aktywnych politycznie i społecznie, a energię do działań uważał za jedną z bardziej godnych pochwały cech charakteru" (Małek, 2010, s. 74). Aktywność społeczna, działania charytatywne, działania na rzecz społeczeństwa mają zarazem bezpośrednie przełożenie na efekty, jakie wynikają z celów i zadań pracy socjalnej poprzez to, że pośrednio przyczyniają się do samostanowienia jednostek, które z kolei przekłada się na samodzielne życia. W tym sensie aktywizm służb społecznych, przyjęcie postawy aktywnej społecznie przyczynia się do dobra, dobrostanu oraz dobrobytu jednostek.

\section{Użyteczność, dobrobyt i praca socjalna}

Jednym z najważniejszych celów, dla których podejmowane są działania pracy socjalnej, jest zmiana społeczna jednostki, co w kategoriach użyteczności oznacza uzyskiwanie samodzielności, oraz korzyści, jakie wynikają z zapoczątkowanej zmiany jej sytuacji życiowej. Natomiast tym, co użyteczne dla jednostki, jest przede wszystkim praca na rzecz zwiększania jej samodzielności. W tym sensie użyteczność wyznacza realizację zadań pracy socjalnej i wiąże się z ich skutecznością oraz efektywnością. Jednakże użyteczność pracy socjalnej jako samostanowienie o sobie umożliwiające realizację celów własnego życia w sposób bezpośredni łączy się z wymiarem etycznym. Utylitarystyczne teorie dotyczące pojmowania dobra i użyteczności są bardzo złożone i wynikają z interpretacji słowa dobrobyt, z zasady maksymalizacji dobra, a także z różnych stanowisk wypracowanych w obrębie utylitaryzmu, takich jak np. utylitaryzm reguł, utylitaryzm czynów czy utylitaryzm preferencji. Jak zaznacza Monika Małek: „Spośród innych podziałów wymienić można przeciwstawienie utylitaryzmu dobrobytu utylitaryzmowi preferencji. Ten pierwszy mówi wprost o zaspokajaniu interesów, co ma prowadzić do szczęścia, natomiast ten drugi wskazuje na zyskiwanie odpowiednich preferencji, które dopiero prowadzą do realizacji interesów. Wyróżnia się też utylitaryzm odwołujący się do sumy pożytku (użyteczności) oraz utylitaryzm opierający się na tzw. pożytku przeciętnym. Z kolei podział na utylitaryzm pozytywny i negatywny wprowadza różne 
kryteria i jakościową cezurę w kalkulacji tego, co jest złem, a co dobrem. Pozytywny utylitaryzm bierze pod uwagę dobrodziejstwa i krzywdy, natomiast negatywny skupia się tylko na krzywdach" (ibidem, s. 83).

Niezależnie od różnych interpretacji znaczeń dobra, dobrobytu w kategoriach użyteczności i pracy socjalnej tym, co decyduje o dobrobycie i użyteczności, jest przekonanie, że wymiar etyczny dobrobytu staje się wymiarem nadrzędnym w tym sensie, że np. dystrybucja dóbr powinna odbywać się w duchu sprawiedliwości społecznej. Właśnie w takim powiązaniu użyteczność oraz dobrobyt znajdują swoje praktyczne zastosowanie i wpisują się w zadania pracy socjalnej. Mill, proponując swoje rozwiązania w obszarze polityki społecznej opartej na mądrej i racjonalnej polityce socjalnej, podkreślał, że dobrobyt jako polepszenie losu ludzi wynika z relacyjnego połączenia wymiaru etycznego oraz uwarunkowań społeczno-ekonomicznych. W etyce utylitarystycznej podstawowym założeniem pojmowania użyteczności dobra jest przyjęcie kategorii dobra jako dobra dla kogoś, co podkreśla Robert E. Goodin w swoim eseju zatytułowanym Użyteczność $i$ dobro: „Cechą wyróżniającą utylitaryzm jest przekonanie, że jeśli jakaś rzecz ma być dobra, to musi być dobra dla kogoś. W swym najogólniejszym sensie 'użyteczny' znaczy tyle, ile 'przydatny'. Utylitaryzm całkiem rozsądnie pyta, po co w końcu mielibyśmy domagać się nikomu do niczego nieprzydatnych gestów? A jednak każda teoria moralności, dogmat religijny czy zasada etyczna, która odmawia otwartego umieszczenia w centrum swej uwagi względów użyteczności i pożytku, będzie musiała domagać się od czasu do czasu właśnie takich pustych gestów" (Goodin, 2002, s. 284). Miarą dobra dla kogoś jest więc jego użyteczność znacząca tyle samo co przydatność. Dobro jest dobrem dla kogoś, jeśli przyczynia się do polepszenia losu jednostki* .

To, jak się zdaje, na pierwszy rzut oka atrakcyjne przekonanie zawiera jednak szereg nieścisłości, ponieważ np. w wersji utylitaryzmu, podstawę którego wyznacza hedonizm, pojęcie dobra dla kogoś może prowadzić do przekonania, że to, co dobre dla kogoś wiąże się tylko z realizacją przyjemności i unikania cierpienia, co z kolei może prowadzić do przekonania, że tylko postawa hedonizmu może prowadzić do

\footnotetext{
* Idea dobra dla kogoś jest bardzo mocno obecna w założeniach L'Arche. Nie jest to jednak wersja utylitarna, ale relacyjno-dialogiczna oparta na zaufaniu, przyjaźni, życzliwości, wrażliwości, czułości i empatii wobec Innych. W swej wspólnotowej wersji niesienie dobra dla kogoś jest zarazem związane z wejściem na drogę przemiany siebie samego, co staje się możliwe w relacji towarzyszenia i przebywania z dorosłymi osobami z niepełnosprawnością intelektualną, którzy są światłem przemieniającym świat oparty na zysku i konsumpcji. Natomiast wspólnotowy wymiar dobra dla kogoś jest w L'Arche pewnym procesem przejścia od wspólnota dla mnie do ja dla wspólnoty, co należy rozumieć jako przejście od egoizmu do mitości czego efektem jest jednocząco-różnorodna przebaczająca wspólnota radości. Te wątki rozwija Jean Vanier w książce zatytułowanej Wspólnota miejscem radości i przebaczenia (Vanier, 2011).
} 
dobrobytu. Inna interpretacja użyteczności i dobrobytu, na którą zwraca uwagę R.E. Goodin, wynika $\mathrm{z}$ analizy zaspokajania interesów i zyskiwania preferencji i wiąże się z wyważeniem interesów i preferencji: „Interesy związane z dobrobytem to tylko zbiór ogólnie scharakteryzowanych dóbr, jakie ludzie będą musieli mieć, zanim pójdą za jakąś bardziej konkretną preferencją. Można wykazać, że zdrowie, dach nad głową, środki do życia i tym podobne są tego rodzaju interesami, użytecznymi dobrami niezależnie od konkretnych zamiarów i planów konkretnych ludzi” (ibidem, 286). Dobrobyt i użyteczność definiowane w duchu przydatności i praktycznego zastosowania mogą więc prowadzić do różnych wniosków, dlatego też ich zastosowanie wymaga wiedzy, rozsądku i mądrości. Zauważa to także Goodin, który uważa, że pomimo różnych interpretacji użyteczności i dobrobytu można znaleźć jaką́ jedną orientację: „Droga, która doprowadziła nas do określenia użyteczności jako maksymalizacji dobrobytu może się wydawać długa i okrężna. Ale niezależnie od tego, jak ta droga była kręta, zauważmy, że ten ostateczny wniosek, z podstawowym poglądem, od którego zaczęliśmy. Użyteczność to przede wszystkim kwestia pożytku; cała wartość ogólnie scharakteryzowanych dóbr, których ochronę utylitaryści mają na względzie, tkwi w tym, że są one pożyteczne dla najrozmaitszych planów życiowych” (ibidem, s. 287).

Współczesne teorie społeczne koncentrują się przede wszystkim na społecznych, ekonomicznych i kulturowych uwarunkowaniach dobrobytu, ich złożoności i różnorodności. Z tych powodów użyteczność jako praktyczne zastosowanie w pracy socjalnej zostaje rozszerzona o umiejętności rozpoznawania konkretnych sytuacji, ponieważ związek pomiędzy uwarunkowaniami społecznymi i jednostkowymi, w kontekście realizacji jej celów i zadań pracy socjalnej, które mają prowadzić do realizacji założonego celu, można rozwiązywać na wiele różnych sposobów. Użyteczność pracy socjalnej to właściwie rozpoznawanie rzeczywistości i jej mechanizmów społecznych, co podkreśla David Howe: „Im lepiej rozumiemy świat, tym sprawniej w nim funkcjonujemy. Potrzebę poznania mechanizmów rządzących rzeczywistością odczuwamy jeszcze silniej, jeśli przyszło nam działać w trudnych, niespokojnych warunkach. Tak jest w przypadku pracy socjalnej. Pracownicy socjalni na codzień stykają się z ludźmi pogrążonymi w życiowych tarapatach i stresie. Operują $\mathrm{w}$ rejonach naznaczonych nierównościami społecznymi, niesprawiedliwym podziałem pieniędzy, władzy i szans życiowych. Materia pracy socjalnej jest więc delikatna. Aby działać z wyczuciem, a zarazem skutecznie, pracownik socjalny musi umieć trafnie rozpoznać sytuację" (Howe, 2011, s. 17). Każda sytuacja jest złożona, dlatego wymaga rozpatrzenia jej z wielu stron. $\mathrm{Z}$ tych powodów w pracy socjalnej ważnym staje zarówno szeroko pojęte rozpoznawanie mechanizmów społecznych po to, aby można było realizować kryterium użyteczności, ujawniające się w praktycznym jej wymiarze i w wymiernych efektach. Problem rozpoznawania mechanizmów rządzących rzeczywistością w kategoriach użyteczności i pracy socjalnej 
podejmuje również Roger Hennessey. Uważa on, że użyteczność podejmowanych działań będzie pełna, jeśli zostanie wzbogacona również o wyznaczone i uznane zasady działania. Dlatego, jego zdaniem, praca socjalna oparta na utylitaryzmie wymaga wzbogacenia etyką zasad (deontologia). Hennessey uważa, że w obrębie pracy socjalnej podejścia te zachodzą na siebie, wzajemnie się warunkują i uzupełniają: „Zasady mają za zadanie pomóc ci wybrać sposób działania, podczas gdy system etyczny kładzie nacisk na przewidywanie konsekwencji zamierzonych przez ciebie działań. Podstawową zasadą w tym przypadku jest działanie mające na celu zdziałanie jak najwięcej 'dobra' i 'radości' dla jak największej ilości ludzi. Ten sposób myślenia o etyce zdrowego rozsądku, zwanej utylitaryzmem, wiąże się również z indywidualną i społeczną sprawiedliwością w takim sensie, że 'największe dobro' może być rozumiane jako sprawiedliwa dystrybucja bogactwa pomiędzy członkami społeczeństwa (...). Jak wszystkie systemy etyczne, utylitaryzm również ma swoje wady. Przykładowo, kształtowanie polityki społecznej opartej na podziale dóbr wszystkich, niesie ze sobą trudności z traktowaniem mniejszości, których jakość życia może ulec pogorszeniu kosztem polepszenia poziomu życia większości. Od swojego powstania w XIX w, utylitarni filozofowie próbowali poradzić sobie z podobnymi trudnościami, a ich filozofia wywarła wielki wpływ na politykę społeczną i zdrowotną Wielkiej Brytanii” (Hennessey, 2014, s. 159).

W opisie dokonanym przez Hennesseya obok rozpoznania mechanizmów społecznych, użyteczność łączy się ze społeczną i indywidualną sprawiedliwością mającą na celu dobro jak największej ilości jednostek, dzięki sprawiedliwej dystrybucji bogactwa. W tym sensie nawiązuje on również do Milla, o czym świadczy podkreślanie specyfiki uwarunkowań społecznych, wykorzystywania zasad wypracowanych w etyce utylitarystycznej oraz jej zastosowania w rozwiązywaniu konkretnych problemów społecznych. Hennessey zwrócił także uwagę na zasady, które pomagają wybrać odpowiedni system etyczny i zasady działania prowadzące do realizacji określonego celu wynikającego z pojęcia dobra dla kogoś. W tym kontekście warto ponownie nawiązać do Milla i jego założenia, że do dobrobytu przyczyniają się takie wartości, jak np. indywidualny rozwój. Mill w swoim eseju $O$ wolności w rozdziale zatytułowanym $O$ indywidualności jako jednym z elementów dobrobytu pisze, że: „Największą trudnością, jaką spotykamy przy wysuwaniu tej zasady, nie jest ocena środków prowadzących do uznanego celu, lecz obojętność ludzi dla samego celu. Gdyby rozumiano, że swobodny rozwój indywidualności jest jednym z zasadniczych składników dobrobytu; że jest to nie tylko element współrzędny z tym wszystkim, co nazywamy cywilizacją, wykształceniem, wychowaniem i kulturą, lecz także niezbędna część i warunek tych rzeczy, nie byłoby niebezpieczeństwa zlekceważenia wolności i nie przedstawiałoby wielkiej trudności wyznaczenie granicy między nią a kontrolą społeczną" (Mill, 2012, s. 156). 


\section{Empowerment i użyteczność pracy socjalnej}

Mówiąc więc o pojęciu dobra dla kogoś, należy stwierdzić, że w ujęciu Milla dobro dla kogoś wynika z ujęcia dobrobytu i użyteczności jako polepszanie losu ludzkości w relacji do takich wartości, jak indywidualny rozwój czy wolność jednostki. Tak więc dokonywanie wyborów dla polepszania losu ludzkiego przez dobrobyt i użyteczność jako dobro dla kogoś to nic innego jak wybieranie tego, co najlepsze dla samostanowienia o sobie i uzyskiwania samodzielności. W myśli filozoficznej Milla, poprzez podkreślenie takich wartości jak samodzielność, rozwój indywidualny i społeczny, ujawnia się również związek pomiędzy metodą empowermentu pojmowanego jako upodmiotowienie, emancypacja oraz jako rozwój potencjału drzemiącego w człowieku a pracą socjalną rozumianą jako realizacja uspołecznienia za pomocą procesu upodmiotowienia, podstawę którego stanowi właśnie samostanowienie, co podkreśla Mel Gray i Stephen A. Webb: „Praca socjalna to poniekąd odpowiedź na próby pogodzenia wolności indywidualnej z solidarnością społeczną. To instytucja spoteczna, za pośrednictwem której jednostki dostają, to, czego potrzebują, wybierając dla siebie 'dobro'. W języku współczesnej pracy socjalnej często określa się to pojęciem empowerment" (Gray, Webb 2012, s. 9). Przywołanie najważniejszego przesłania Milla, jakim jest walka z biedą, polepszenie losu ludzkości realizowane przez odwołanie się do użyteczności i dobrobytu oraz takie wartości jak samostanowienie, wolność jednostkowa oparta na krytyczności, na budzeniu świadomości, ukazuje je w formie związku pomiędzy jego ideami społeczno-etycznymi, dążeniami emancypacyjnymi a takim empowermentem, o którym pisze Chris Beckett: „W dyskursie o empowermencie w sposób ukryty, a często jawny, występuje idea budzenia świadomości. Celem empowermentu jest umożliwienie zdobycia władzy osobom, które uważają się za bezsilne. Społeczeństwo osłabiło grupy ludzi przekonując je, by umieszczali swoje trudności wewnątrz siebie jako słabości osobiste, a nie na zewnątrz jako niesprawiedliwość strukturalną. Książka Paulo Freire'a Pedagogika uciśnionych (Pedagogy of the Oppressed, 1986) jest szeroko cytowana w literaturze empowermentu i, jak wskazuje tytuł książki, Freire uznawał empowerment za działanie pedagogiczne (czyli edukacyjne) w swym charakterze. Pozwala ona, by ludzie uciskani, uczyli się dostrzegać sprzeczności społeczne, polityczne i ekonomiczne (ibidem, s. 66, moje wyróżnienie). „Ludzie uciskani i krzywdzeni często błędnie lokują swoje trudności w samych sobie, dlatego wydaje się sensowne przeprowadzenie procesu empowermentu, by skorygować te błędne przekonania i umożliwić ludziom uzyskania bardziej realistycznego obrazu świata, niż ten, którego narzucili im ciemiężcy i krzywdziciele" (Beckett, 2010, s. 146). W tym sensie związek pomiędzy empowermentem a użytecznością pracy socjalnej jest oczywisty, a te dwa pojęcia pozostają we wzajemnej korelacji. 


\section{Podsumowanie}

Praca socjalna i jej wartość w społeczeństwie współczesnym, którego ważnym aspektem pozostaje pojęcie użyteczności, wskazuje, że jest ona nieobojętna na zmiany, jakie zachodzą w społeczeństwie oraz na to, że ocena jej wartości w dużej mierze zależy od społecznie uznawanych wartości i ich praktycznego zastosowania. Ale praca socjalna w swym pragmatycznym nastawieniu nie może też zapominać o dążeniu do zapewnienia godnego życia, ponieważ godność jest podstawowym warunkiem dobrego życia. Dlatego użyteczność pracy socjalnej swoje moralne oparcie czerpie z przekonania, że dobro powinno być dobrem dla kogoś, czyli takim, które przyjmuje konkretną postać i w tym sensie dobro dla kogoś staje się dobrem jednostki jako wybór dobra dla siebie w relacji do dobra dla innych. Wynika stąd również, że przemyślenie wartości pracy socjalnej przez pryzmat kategorii użyteczności i empowermentu powinno łączyć się z wartością pracy socjalnej, które powinny stanowić podłoże jej instytucjonalnych, systemowych form jako form uczestniczących $\mathrm{w}$ procesie uspołecznienia jako upodmiotowienia.

Co wyznacza zatem granicę $\mathrm{w}$ procesie upodmiotowienia oraz granicę pracy socjalnej w procesie wybierania dobra dla kogoś jako dobra dla innych i dobra dla siebie? W kontekście powyższych rozważań można powiedzieć, że z perspektywy etycznej granicę przejścia w proces upodmiotowienia wyznacza spotkanie z innym doznającym krzywdy. Granicę tę można ująć w kategoriach Axela Honnetha przez uznanie społeczne, a dokładniej, przez brak uznania, którego przyczyny i konsekwencje opisuje on w książce Walka o uznanie. Moralna gramatyka konfliktów spotecznych (Honneth, 2012).

\section{Bibliografia}

Beckett C. (2010). Podstawy teorii dla praktyków pracy socjalnej. Przeł. M. Jasiński, B. Maliszewska. Warszawa: Wydawnictwo Akademii Pedagogiki Specjalnej.

Gray M., Webb A.S. (2012). Praca socjalna. Teorie i metody. Przeł. B. Maliszewska. Warszawa: Wydawnictwo Naukowe PWN.

Goodin E.R. (2002). Użyteczność i dobro. przeł. P. Łuków. W: P. Singer, (red.), Przewodnik po etyce. Warszawa: Wydawnictwo Książka i Wiedza.

Hennessey R. (2014). Umiejętności interpersonalne w pracy socjalnej. Warszawa: Centrum Rozwoju Zasobów Ludzkich.

Honneth A. (2012). Walka o uznanie. Moralna gramatyka konfliktów spotecznych.

Kraków: Zakład Wydawniczy Nomos. 
Howe D. (2011). Krótkie wprowadzenie do teorii pracy socjalnej. Przeł. P. Matela. Warszawa: Instytut Rozwoju Służb Społecznych.

Maj J. (2017). Użyteczno-emencypacyjny potencjat dialogul dziatanie dla dobra innych. W: D. Jankowska, (red.). Pedagogika dialogu. Emancypacyjny potencjat dialogu. Warszawa: Wydawnictwo APS.

Małek M. (2010). Liberalizm etyczny Johna Stuarta Milla. Wspótczesne ujęcia u Johna Graya i Petera Singera. Wrocław: Wydawnictwo Uniwersytetu Wrocławskiego.

Mill J.S. (2012). Utylitaryzm, O wolności. Przeł. M. Ossowska. Warszawa: Wydawnictwo PWN.

Rybczyńska A.D., Olszak-Krzyżanowska B. (1995). Aksjologia pracy socjalnej-wybrane zagadnienia. Warszawa: Wydawnictwo Naukowe Scholar.

Vanier J. (2011). Wspólnota miejscem radości i przebaczenia. Przeł. M. Żurowska. Poznań: Wydawnictwo W drodze.

\section{Utility, Empowerment and Social Work}

Summary: Social work utility can be considered a value helpful in achieving principles and objectives set forthe social assistance system in contemporary society. The concept of empowerment, on the other hand, interpreted in a spirit of individuals' self-determination and social sensitivity, reminds us that lack of social recognition deprives individuals of subjectivity and self-determination. The paper points out interrelations between utility and empowermentin the field of social work, which can contribute to identification of the ethical dimension of social issues and help address and deal with social problems both in the overall context of the entire social assistance system and in local settings with respect for individual freedom. This occurs when utility is defined in a spirit of usefulness and practical application associated with action for the good of others, while the concept of empowerment insists that social work practice should not lose sight of the subjectivity of individuals and social groups in the context of their self-determination and self-direction.

Keywords: utility, empowerment, social work, self-determination, utilitarianism, good for others. 